\title{
KETERAMPILAN SISWA MEMANFAATKAN PERPUSTAKAAN SEBAGAI SUMBER BELAJAR DI SMK NEGERI 3 OKU SELATAN
}

\author{
Johan Eka Wijaya. DN \\ Universitas Baturaja \\ johanekawijaya@gmail.com
}

\begin{abstract}
The objective of this research is to know the students' creativity in using Library as learning source at SMK Negeri 3 OKU Selatan. This Research is quantitative research. The methodology of this research is descriptive method. This research is done by the students at SMK Negeri 3 OKU Selatan that the total number are 235 students. Then, the questionnaire is used to collect data of this reaserch. The result of this research shows to the students that the students' creativity in using the library as learning source at SMK Negeri 3 OKU Selatan is enough category with 69,1\%. Students' creativity in collecting the information at SMK Negeri 3 OKU Selatan is rearched based on the total average of always category and seldom category is 62,98\% with enough category. Then, students' creativity in creating the summary and information organizaation at SMK Negeri 3 OKU Selatan who answering always and seldom is 67,66\% with enough category. Students' creativity in analyzing, interpreting and evaluating the information at SMK Negeri 3 OKU Selatan who answer always and seldom is 70,73\% with enough category. And the students' creativity in using information at SMK Negeri 3 OKU Selatan that answer always and seldom is 75\% with enough category. So, it can be concluded that the students at SMK Negeri 3 OKU Selatan that has creativity in collecting information, creating the summary and information organization, creativity in analyzing, interpreting and information evaluation, so it means that the students' creativity in using information have been done in good enough category.
\end{abstract}

Keywords: Creativity, Library, Learning Source

\begin{abstract}
Abstrak
Penelitian ini bertujuan untuk mengetahui Keterampilan Siswa Memanfaatkan Perpustakaan Sebagai Sumber Belajar di SMK Negeri 3 OKU Selatan. Jenis penelitian ini adalah kuantitatif. Metode yang digunakan adalah metode deskriptif. Penelitian ini dilaksanakan pada siswa SMK Negeri 3 OKU Selatan yang berjumlah 235 orang. Alat pengumpulan data dalam penelitian ini menggunakan angket. Hasil penelitian kepada siswa menunjukkan bahwa keterampilan siswa memanfaatkan perpustakaan sebagai sumber belajar di SMK Negeri 3 OKU Selatan berada pada kategori cukup dengan 69,1\%. Rincian keterampilan siswa mengumpulkan informasi di SMK Negeri 3 OKU Selatan dicapai berdasarkan penjumlahan rata-rata pilihan selalu dan sering 62,98\% dengan kriteria "cukup". Keterampilan siswa mengambil intisari dan pengorganisasian informasi di SMK Negeri 3 OKU Selatan yang menjawab selalu dan sering 67,66\% dengan kriteria "cukup". Keterampilan siswa menganalisis, menginterpretasikan dan mengevaluasi informasi di SMK Negeri 3 OKU Selatan yang menjawab selalu dan sering 70,73\% dengan kriteria "cukup". Dan keterampilan siswa menggunakan informasi di SMK Negeri 3 OKU Selatan yang menjawab selalu dan sering 75\% dengan kriteria "cukup". Sehingga dapat disimpulkan bahwa siswa di SMK Negeri 3 OKU Selatan dalam keterampilan mengumpulkan informasi, mengambil intisari dan
\end{abstract}


pengorganisasian informasi, keterampilan menganalisis, menginterpretasikan dan mengevaluasi informasi, serta keterampilan menggunakan informasi sudah dilakukan dengan "cukup baik".

Kata Kunci: Keterampilan, Perpustakaan, Sumber Belajar

\section{A. PENDAhULUAN}

Dalam Undang-Undang Nomor 43 Tahun 2007 tentang perpustakaan, pada pasal 23 ayat 1 disebutkan setiap sekolah/madrasah menyelengarakan perpustakaan yang memenuhi Standar Nasional Pendidikan. Dan dalam UndangUndang Nomor 20 Tahun 2003 tentang Sistem Pendidikan Nasional, pada pasal 45 disebutkan bahwa setiap satuan pendidikan formal dan nonformal menyediakan sarana dan prasarana yang memenuhi keperluan pendidikan sesuai dengan pertumbuhan dan perkembangan fisik, kecerdasan intelektual, sosial, emosional, dan kejiwaan peserta didik. Sarana dan prasana yang dimaksud dalam undang-undang tersebut diantaranya penyediaan perpustakaan di sekolah.

Siswa sekolah menengah atas telah ditanamkan akan pentingnya membaca sejak dini dengan berbagai bahan pustaka yang akan menunjang dan meningkatkan hasil belajar, seperti yang dikemukan pada hasil penelitian yang dilakukan oleh Wijayanti, Efendi, dan Warmiyati (2012) bahwa peran perpustakaan sangat penting dalam membangkitkan minat baca. Pengetahuan dan minat membaca siswa bertambah sejak ada perpustakaan. Oleh karena itu disediakannya perpustakaan yang ada di SMK Negeri 3 OKU Selatan agar siswa dapat memanfaatkan waktu yang ada untuk membaca berbagai jenis buku maupun sumber belajar yang lainnya, karena melalui perpustakaan siswa dapat mendidik dirinya secara berkesinambungan. Hal tersebut sesuai dengan kajian yang dikemukakan oleh Rosinar (2014) bahwa perpustakaan sekolah harus selalu terbuka 24 jam selama tujuh hari dalam seminggu. Tidak ada alasan lagi bagi siswa untuk tidak mengunjungi perpustakaan manakala mereka mendapat tugas dari guru yang mengharuskan mendatangi perpustakaan untuk memperoleh informasi yang diperlukan.

Hasil penelitian lain juga dikemukakan oleh AP Akbar, YT Komarudin (2015) bahwa terdapat pengaruh yang positif dan signifikan antara perilaku belajar peserta didik terhadap pemanfaatan perpustakaan sekolah sebagai sumber belajar di SMP Negeri 5 Bandung.

Perpustakaan juga akan sangat berguna apabila siswa ditugaskan untuk meminjam sumber materi (buku) pada saat awal tahun ajaran baru dan ketika guru mengharuskan siswa memiliki sumber belajar dari perpustakaan. Siswa SMK Negeri 3 OKU Selatan sebagian besar akan selalu ke perpustakaan pada saat tertentu, seperti siswa kelas XII yang akan menghadapi ujian nasional dan hanya siswa yang kreatif dan yang akan mengikuti lomba olimpiade mempunyai inisiatif sendiri untuk ke perpustakaan.

\section{B. KAJIAN LITERATUR}

1. Hakikat Belajar

Belajar dan pembelajaran adalah dua aktivitas yang hampir tidak dapat dipisahkan satu dari lainnya, terutama dalam prakteknya disekolah-sekolah. Bahkan apabila keduannya telah digerakkan secara sadar dan bertujuan, maka rangkaian interaksi belajar mengajar akan segera terjadi. Menurut Slameto (2013:3) belajar adalah "suatu proses usaha yang dilakukan seseorang untuk memperoleh suatu perubahan tingkah laku yang baru secara keseluruhan, sebagai hasil 
pengalamannya sendiri dalam interaksi dengan lingkungannya". Perubahan yang terjadi dalam diri seseorang banyak sekali baik sifat maupun jenisnya karena itu sudah tentu tidak setiap perubahan dalam diri seseorang merupakan perubahan dalam arti belajar.

2. Sumber Belajar

Menurut Wina (2006:175) "sumber belajar adalah segala sesuatu yang dapat dimanfaatkan oleh siswa untuk mempelajari bahan dan pengalaman belajar sesuai dengan tujuan yang hendak dicapai". Mengacu pada definisi sumber belajar yang diberikan oleh Association for Education Communication Technologhy (AECT) dalam Sitepu (2014:17) maka pengertian sumber belajar adalah "berbagai atau semua sumber baik berupa data, orang dan wujud tertentu yang dapat digunakan oleh siswa dalam belajar, baik secara terpisah maupun secara terkombinasi sehingga mempermudah siswa dalam mencapai tujuan belajar".

3. Hakikat Perpustakaan

Menurut Yaya (2014:3) menyatakan pengertian "perpustakaan sekolah dapat diartikan sebagai tempat terhimpunnya berbagai bahan pustaka, baik cetak maupun noncetak, seperti buku, majalah, surat kabar, film, video, dan $\mathrm{CD}$ guna menunjang kegiatan pembelajaran di sekolah dasar yang bersangkutan".

Menurut hasil kajian S Setiani, H Silvana (2017) dikemukakan bahwa perpustakaan sekolah merupakan bagian penting bagi siswa untuk menunjang keberlangsungan proses belajar mengajar, karena perpustakaan sekolah selain mempunyai fungsi penelitian, pusat informasi, dan rekreasi juga sebagai sarana pendidikan bagi siswa.
Tujuan dari perpustakaan sekolah adalah untuk memenuhi kebutuhan pemustaka khususnya untuk murid dan guru di sekolah.

Perpustakaan sekolah sebagai tempat belajar dapat dimanfaatkan peserta didik untuk belajar kelompok maupun individu dalam menyelesaikan tugas mereka saat pembelajaran. Perpustakaan sekolah sebagai pengelola sumber belajar, selain itu perpustakaan sekolah juga dapat mengolah berbagai informasi yang bukan hanya sebagai sumber belajar bagi pendidikan saja tapi berbagai pendidikan saja tapi berbagai ilmu pengetahuan yang dapat disediakan seperti ilmu tentang kesehatan, novel, cerpen, budaya masyarakat, dan berbagai bidang ilmu lainnya.

4. Keterampilan Memanfaatkan Perpustakaan Sebagai Sumber Belajar

Achsin dalam Azhar (2013:100) pemafaatan perpustakaan memerlukan keterampilan sebagai berikut:

a. Keterampilan mengumpulkan informasi, yang meliputi keterampilan:

1) Mengenal sumber informasi dan pengetahuan; dan

2) Menentukan lokasi sumber informasi berdasarkan sistem klasifikasi perpustakaan, cara menggunakan katalog dan indeks.

Klasifikasi berasal darikata "classification" (bahasa Inggris). Kata "classification" ini berasal dari kata "to classify", yang berarti menggolongkan dan menempatkan benda-benda yang sama di suatu tempat.

Menurut Mulyani dalam Suryosubroto (2009, hlm. 235) Katalogisasi adalah pembuatan uraian singkat tentang keterangan 
sesuatu koleksi, yang dapat dipergunakan sebagai wakil dari koleksi yang bersangkutan, agar mudah ditemukan.

3) Menggunakan bahan pustaka baru, bahan referensi seperti ensiklopedia, kamus, buku tahunan, dan lain-lain.

Menurut Pawit dan Yaya (2010:12) buku referensi atau buku rujukan adalah buku-buku yang memuat informasi secara khusus sehingga dapat menjawab atau menunjukkan secara langsung bagi pembacanya. Karena buku-buku referensi ini bersifat langsung jawab tadi, maka biasanya hanya dibaca di perpustakaan saja, tidak boleh dipinjam untuk dibawa ke luar/pulang.

Keterampilan mengambil intisari dan mengorganisasikan informasi, seperti:

1) Memilih informasi yang relevan dengan kebutuhan dan masalah; dan

2) Mendokumentasikan informasi dan sumbernya.

b. Keterampilan menganalisis, menginterpretasikan dan mengevaluasi informasi, seperti:

1) Memahami bahan yang dibaca;

2) Membedakan antara fakta dan opini; dan

3) Menginterpretasikan informasi baik yang saling mendukung maupun berlawanan.

c. Keterampilan menggunakan informasi, seperti:

1) Memanfaatkan intisari informasi untuk mengambil keputusan dan memecahkan masalah;

2) Menggunakan informasi dalam diskusi; dan

3) Menyajikan informasi dalam bentuk tulisan.

\section{METODOLOGI PENELITIAN}

Jenis Penelitian yang digunakan dalam penelitian ini adalah penelitian kuantitatif dengan metode deskriptif. Populasi dari penelitian ini adalah siswa SMK Negeri 3 OKU Selatan yang terdiri dari 674 siswa. Sampel penelitian ini sebesar 35\% dari populasi yang berjumlah 674 orang siswa $(35 \%$ × $674=235)$. Teknik pengambilan sampel dalam penelitian dilakukan secara acak, guna memperoleh data tentang keterampilan memanfaatkan perrpustakaan sebagai sumber belajar di SMK Negeri 3 OKU Selatan. Untuk lebih jelasnya tergambar pada tabel berikut ini.

Tabel 1

Populasi dan Sampel

\begin{tabular}{cccc}
\hline No & Kelas & Populasi & Sampel \\
1 & $\mathrm{X}$ & 222 & 64 \\
\hline 2 & $\mathrm{XI}$ & 226 & $\mathrm{8} 2$ \\
3 & $\mathrm{XII}$ & 226 & 89 \\
\hline \multicolumn{2}{c}{ Jumlah } & 674 & $\mathbf{2 3 5}$
\end{tabular}

Teknik yang digunakan dalam pengumpulan data adalah dengan kuesioner, dan alat pengumpulan data yang digunakan pada penelitian ini adalah berupa angket yang terdiri dari seperangkat pertanyaanpertanyaan yang diberikan kepada siswa SMK Negeri 3 OKU Selatan.

Teknik analisis data yang akan digunakan dalam penelitian ini adalah dengan menggunakan teknik deskriptif persentatif dengan rumus perhitungan sebagai berikut:

$$
P=\frac{f}{N} \times 100 \%
$$

(Sudijono, 2014:43)

Keterangan:

F: Frekuensi yang dicari persentasenya.

$\mathrm{N}$ : Number of class.

P: Angka persentase. 
Untuk menganalisis data penelitian menggunakan rumus persentase yang kemudian dikonsultasikan pada kriteria pengambilan keputusan sebagai berikut:

\section{Tabel 2}

Rentang Nilai

\begin{tabular}{llll}
\hline Interval & \multicolumn{2}{l}{ Nilai } & \\
Persentase & \multicolumn{2}{l}{ Pcrubahan } & Keterangan \\
Tingkat & \multicolumn{2}{l}{ Skala Empat } & \\
\cline { 2 - 3 } Pernguavalan & $1-4$ & I2-A & \\
\hline $86-100$ & 4 & A & Baik Sekali \\
$76-85$ & 3 & B & Baik \\
$56-75$ & 2 & C. & Cukup \\
$10-55$ & 1 & D & Kurang \\
\hline
\end{tabular}

(Nurgiantoro 2012: 253)

\section{HASIL DAN PEMBAHASAN}

1. Keterampilan Mengumpulkan Informasi Berdasarkan hasil angket pada keterampilan mengumpulkan informasi yang dilakukan oleh siswa SMK Negeri 3 OKU Selatan tergambar secara keseluruhan bahwa 10 pernyataan yang dijawab oleh responden, untuk jawaban selalu berjumlah 634 dengan rata-rata 63,4 dan persentase $26,98 \%$, jawaban sering berjumlah 846 dengan rata-rata 84,6 dan persentase $36 \%$, jawaban kadang-kadang berjumlah 712 dengan rata-rata 71,2 dan persentase 30,30\% jawaban tidak pernah berjumlah 158 dengan rata-rata 15,8 dan persentase $6,72 \%$. Jika dilihat dari kriteria pedoman penilaian persentase selalu dan sering yaitu $26,98 \%+36 \%=62,98 \%$. Dengan demikian dapat disimpulkan bahwa keterampilan mengumpulkan informasi sudah dilakukan siswa dengan cukup.

2. Keterampilan Mengambil Intisari dan Pengorganisasian Informasi

Berdasarkan hasil angket pada keterampilan mengambil intisari dan pengorganisasian informasi yang dilakukan oleh siswa SMK Negeri 3 OKU Selatan tergambar secara keseluruhan bahwa 6 pernyataan yang dijawab oleh responden, untuk jawaban selalu berjumlah 467 dengan rata-rata 77,83 dan persentase $33,12 \%$, jawaban sering berjumlah 487 dengan rata-rata 81,17 dan persentase $34,54 \%$, jawaban kadangkadang berjumlah 357 dengan rata-rata 59,50 dan persentase 25,32\% jawaban tidak pernah berjumlah 99 dengan ratarata 16,50 dan persentase $7,02 \%$. Jika dilihat dari kriteria pedoman penilaian persentase selalu dan sering yaitu $33,12 \%+34,54 \%=67,66 \%$. Dengan demikian dapat disimpulkan bahwa keterampilan mengambil intisari dan pengorganisasian informasi sudah dilakukan siswa dengan cukup.

3. Keterampilan Menganalisis, Menginterpretasikan dan Mengevaluasi Informasi

Berdasarkan hasil angket pada keterampilan menganalisis, menginterpretasikan dan mengevaluasi informasi yang dilakukan oleh siswa SMK Negeri 3 OKU Selatan tergambar secara keseluruhan bahwa 8 pernyataan yang dijawab oleh responden, untuk jawaban selalu berjumlah 617 dengan rata-rata 77,12 dan persentase $32,88 \%$, jawaban sering berjumlah 710 dengan rata-rata 88,75 dan persentase $37,85 \%$, jawaban kadang-kadang berjumlah 481 dengan rata-rata 60,12 dan persentase $25,65 \%$ jawaban tidak pernah berjumlah 68 dengan rata-rata 8,5 dan persentase 3,63\%. Jika dilihat dari kriteria pedoman penilaian persentase selalu dan sering yaitu $32,88 \%+37,85 \%=70,73 \%$. Dengan demikian dapat disimpulkan bahwa keterampilan menganalisis, menginterpretasikan dan mengevaluasi informasi sudah dilakukan siswa dengan cukup. 
4. Keterampilan Menggunakan Informasi Berdasarkan hasil angket pada keterampilan menggunakan informasi yang dilakukan oleh siswa SMK Negeri

3 OKU Selatan tergambar secara keseluruhan bahwa 4 pernyataan yang dijawab oleh responden, untuk jawaban elalu berjumlah 350 dengan rata-rata 87,5 dan persentase $37,23 \%$, jawaban sering berjumlah 355 dengan rata-rata 88,75 dan persentase $37,77 \%$, jawaban kadang-kadang berjumlah 193 dengan rata-rata 48,25 dan persentase 20,53\% jawaban tidak pernah berjumlah 42 dengan rata-rata 10,5 dan persentase 4,47\%. Jika dilihat dari kriteria pedoman penilaian persentase selalu dan sering yaitu $37,23 \%+37,77 \%=75 \%$. Dengan demikian dapat disimpulkan bahwa keterampilan menggunakan informasi sudah dilakukan siswa dengan cukup.

Untuk melihat hasil penelitian keterampilan siswa memanfaatkan perpustakaan sebagai sumber belajar di SMK Negeri 3 OKU Selatan secara keseluruhan dapat dilihat pada rekapitulasi data angket hasil penelitian sebagai berikut.

Berdasarkan hasil yang diperoleh dari penyebaran angket pada penelitian keterampilan siswa memanfaatkan perpustakaan sebagai sumber belajar di SMK Negeri 3 OKU Selatan, diperoleh hasil jika dalam keterampilan mengumpulkan informasi oleh siswa total sebesar 62,98\% dengan kriteria cukup. Keterampilan mengambil intisari dan pengorganisasian informasi sebesar $67,66 \%$ dengan kriteria cukup. Keterampilan menganalisis, mengiterpretasikan dan mengevaluasi informasi dengan total $70,73 \%$ dengan kriteria cukup. Dan keterampilan menggunakan informasi memperoleh total $75 \%$ dengan kriteria cukup. Dari hasil keseluruhan pernyataan diperoleh 69,1\% dengan kriteria cukup.

Tabel 3

Rekapitulasi Jumlah Persentase

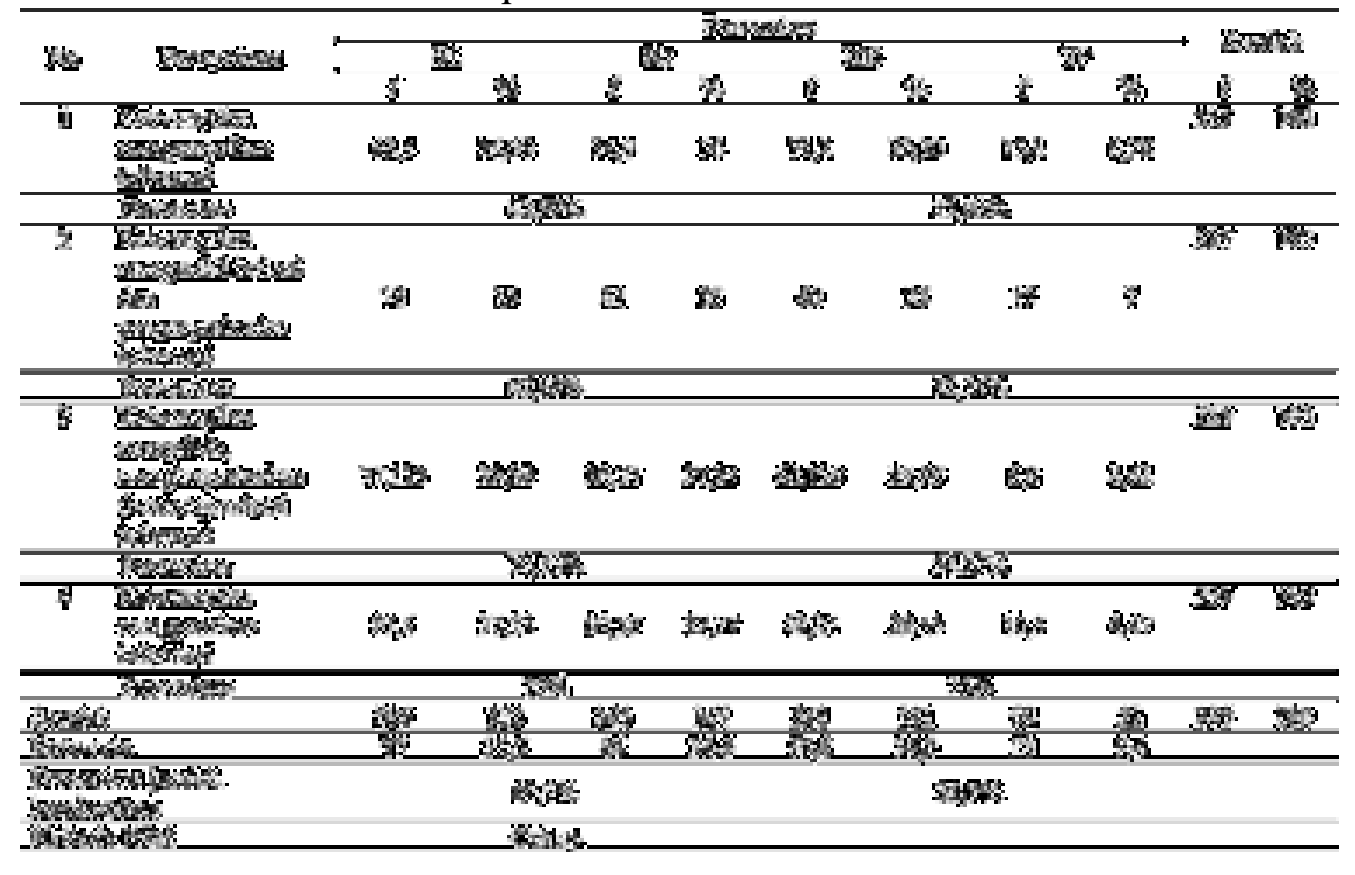




\section{E. SIMPULAN DAN SARAN}

Berdasarkan hasil penelitian keterampilan siswa memanfaatkan perpustakaan sebagai sumber belajar di SMK Negeri 3 OKU Selatan, secara umum sudah dilaksanakan dengan baik. Hal tersebut dapat dilihat dari persentase 69,1\% termasuk kategori "cukup".

Secara khusus hasil penelitian keterampilan siswa memanfaatkan perpustakaan sebagai sumber belajar di SMK Negeri 3 OKU Selatan dapat disimpulkan bahwa keterampilan siswa dalam mengumpulkan informasi di SMK Negeri 3 OKU Selatan mencapai $62,98 \%$ hal ini dapat dinyatakan "cukup". Ini terlihat dari perolehan nilai tertinggi terdapat pada pernyataan tentang mengenal sumber pengetahuan yang tersedia di perpustakaan.

Keterampilan siswa dalam mengambil intisari dan pengorganisasian informasi di SMK Negeri 3 OKU Selatan mencapai $67,66 \%$ hal ini dapat dinyatakan "cukup". Ini terlihat dari perolehan nilai tertinggi terdapat pada pernyataan tentang memilih informasi di perpustakaan disesuaikan dengan kebutuhan dan masalah yang dihadapi.

Keterampilan siswa dalam menganalisis, menginterpretasikan dan mengevaluasi informasi di SMK Negeri 3 OKU Selatan mencapai $70,73 \%$ hal ini dapat dinyatakan "cukup". Ini terlihat dari perolehan nilai tertinggi terdapat pada pernyataan tentang membedakan informasi yang diperoleh berupa fakta atau opini dari buku yang dibaca. Keterampilan siswa dalam menggunakan informasi di SMK Negeri 3 OKU Selatan mencapai $75 \%$ hal ini dapat dinyatakan "cukup". Ini terlihat dari perolehan nilai tertinggi terdapat pada pernyataan tentang memanfaatkan intisari informasi yang didapat di perpustakaan untuk memecahkan masalah.

\section{DAFTAR PUSTAKA}

Akbar, A. P., \& Komarudin, Y. T. (2015). Pengaruh Perilaku Belajar Peserta Didik Terhadap Pemanfaatan Perpustakaan Sekolah Sebagai Sumber Belajar. Jurnal Edulib, 5(2).

Arsyad, Azhar. (2013). Media Pembelajaran. Jakarta: PT. Raja Grafindo Persada.

Nurgiantoro, Burhan. (2012). Penilaian Pembelajaran Bahasa Berbasis Kompetensi. Yogyakarta: BPFE.

Rosinar, E. (2014). Kiat-Kiat Pemberdayaan Perpustakaan Sekolah. Jurnal Edulib, 4(1).

Setiani, S., \& Silvana, H. (2017). Kerjasama Antara Guru dengan Pustakawan dalam Layanan Perpustakaan Sekolah Dasar Hikmah Teladan. Jurnal Edulib, 6(2).

S.H., Wijayanti, Efendi, \& Warmiyati. (2012). Peningkatan Minat Baca Melalui Peran Perpustakaan Sekolah Dasar Di Desa Cisauk, Tangerang. Dharmakarya: Jurnal Aplikasi Ipteks untuk Masyarakat. 1(2) Halaman 109-118.

Sitepu. (2014). Pengembangan Sumber Belajar. Jakarta: PT Raja Grafindo Persada.

Slameto. (2013). Belajar dan Faktor Yang Mempengaruhinya. Jakarta: PT Rineka Cipta.

Sudijono, Anas. (2014). Pengantar Statistik Pendidikan. Jakarta: Rajawali Pers. 
Suhendar, Yaya. (2014). Panduan Petugas Perpustakaan. Jakarta: Prenada Media Group.

Suryosubroto. (2009). Proses Belajar Mengajar di Sekolah. Jakarta: PT Rineka Cipta.

Undang-Undang Nomor 20 Tahun 2003 tentang Sistem Pendidikan Nasional.

Undang-Undang Nomor 43 Tahun 2007 tentang Perpustakaan.

Wina Sanjaya. (2006). Stategi Pembelajaran. Jakarta: Prenada Media Group.

Yusuf, M Pawit dan Yaya Suhendar. (2010). Pedoman Penyelenggaraan Perpustakaan Sekolah. Jakarta: Kencana Prenada Media Group. 